\title{
MANAGEMENT OF POPO VILLAGE DEVELOPMENT STRATEGY AS A MARINE TOURISM VILLAGE IN TAKALAR REGENCY
}

\author{
Andri Machmury \\ Email: andrisakpa@gmail.com \\ Tourism Management Study Program, Department of Tourism, Makassar Tourism \\ Polytechnic, Indonesia
}

\begin{abstract}
The purpose of this research is to find out the right tourism development strategy to be implemented in Popo village as a coastal tourism village in Takalar Regency. The method of this research is descriptive research. The instruments in this study include; Observation of Data Documentation, Interview and Questionnaire. The result of the research shows that the development of tourist villages requires support from various parties so that they can become income for the community in the tourist village. In the development of tourist villages, there are various factors including driving factors and inhibiting factors. The driving factor of the tourist village being the driving force for the promotion of the tourist village will be a factor inhibiting the development of the tourist village so that it can be accepted and managed so that it can be entered as a tourism partner village.
\end{abstract}

Keywords: Tourism Development, Management, Marine Tourism

\section{Introduction}

The prospect of the tourism industry in Indonesia is very large and promising, considering that Indonesia has abundant natural resources. Tourism is all activities in society related to tourists (Soekadijo, 2001). The tourism sector provides a significant contribution to the national Gross Domestic Product (GDP). Tourism contributes about $4.1 \%$ of GDP directly and 9\% indirectly. The tourism sector is also able to withstand the pressures of the global crisis. Through the 2019 Indonesia Year visit program, the tourism sector managed to capture and bring in 6.5 million foreign tourists, equivalent to USD 7.5 million in foreign exchange (Business news, 2010).

Tourism is considered as an alternative in the economic sector to accelerate poverty reduction in Indonesia and is believed not only to be able to become a mainstay sector in an effort to increase the country's foreign exchange, but also to alleviate poverty (Yoeti 2008). Therefore, the government has an important role in exploring the potential and making policies for tourism development, so that local communities are awakened to their awareness to explore potential and move to build their respective villages and cities. One strategy that thrives and becomes a stakeholder is the tourism village development strategy through community empowerment (Siswanto, 2015). According to Chandler, strategy is a tool to achieve company goals in relation to long-term goals, follow-up programs and resource allocation priorities (Umar, 2010). 
The tourism sector is an important sector in providing income and a source of deficit for development in an area (Kabanova \& Vetrova, 2017). Tourism which is an activity of human movement in traveling temporarily, to a place outside the area where they live with the aim of without intending to make a living (Gunn \& Var, 2020).

In organizing and developing their regions, local governments are required to be able to explore and seek sources of local revenue based on the potentials or wealth owned by the regions by using and managing them properly and optimally. One of the most supportive development potentials is the tourism potential which has not been fully utilized.

Tourism potential is considered to be quite potential as one of the substitute commodities for mining materials that needs to be managed and developed in South Sulawesi Province, especially Takalar Regency. Tourism potential in Takalar Regency consists of 3 (three) categories of tourist attractions, namely tourism, cultural tourism. Marine tourism in Takalar Regency is included in natural tourism.

Tourism activity is a socio-cultural activity that involves a lot of humans in it, so it is natural that in its development the human element becomes the center of attention, both as a subject and object (Saepudin et al., 2018;). With the development of tourism is expected to be able to provide competitiveness against other tourist destinations. This development activity cannot be separated from social, economic and environmental conditions. Therefore, the use of an environment must be carefully planned and controlled in a directed manner. In this case the role of the community is very important, by involving the community in the preparation and planning of tourism in their area, it is expected to be able to increase their participation because there is a sense of ownership and responsibility to maintain and preserve which at the same time improves the community's economy and ultimately improves the welfare of the community (Fitranti, 2014).

In tourism development, facilities and infrastructure are an important factor in the success of tourism development (Bhuiyan et al., 2013). In Takalar Regency, the facilities and infrastructure are considered very inadequate. Like public roads. Takalar Regency has $411 \mathrm{~km}$ of roads. The condition of lightly and heavily damaged roads of $239 \mathrm{~km}$ is commonly found on roads leading to tourist attractions in Takalar Regency.

Coastal tourism objects have great potential in improving the community's economy, at least in improving the economy of the community around the tourist area (Brake \& Edward, 2014). Tourism activities have a broad impact on community activities as a positive impact of the multiplier effect (Rusu, 2011). With the existence of tourism activities, the potential for other activities such as the provision of hotels or guesthouses, food and beverages, souvenirs, local transportation and other small businesses. The current coastal management is still not optimal. Therefore, a strategy is needed in developing tourism potential.

Based on the results of initial observations, the strategies used by the Takalar Regency Tourism Office for marine tourism through ecotourism, among others, are zoonation, development of ODTW (Tourism Attractions), development of tourism objects and attractions by adding supporting facilities and infrastructure for tourists, increasing tourism promotion, community participation in achieving marine tourism development, however, this strategy can run optimally if the attention, participation and consideration of the Takalar Regency Government through the Tourism Office, the community to implement the strategy.

The development of the number of tourists who come to Takalar Regency is not balanced with the development of the existing transportation system. Tourists who come to Takalar Regency are faced with the difficulty of accessing cheap, fast, and comfortable public transportation. 
The existing public transportation is still very limited with routes that are also still limited. This condition is of course very unfavorable for the development of tourism in Takalar Regency in the future.

The tourism potential in Takalar Regency is very promising if it is managed optimally. To create competitiveness with other tourist areas, Takalar Regency must immediately improve. Competitiveness between tourist areas is an unavoidable factor in the world of tourism. Because competitiveness itself will affect the number of tourists visiting.

In this case, one of the villages that has the potential to be developed as a tourism village based on cultural and natural tourism is Popo Village. By looking at the future prospects of tourism which will be very promising in making a major contribution to regional development. Popo Village has the power as a complete tourist attraction for its natural beauty, the hospitality of the village community, the atmosphere is still beautiful and comfortable, has its own uniqueness.

Popo Village is a village administratively located in South Galesong Dis, Takalar Regency, South Sulawesi Province, which is famous for its beaches and natural scenery. Popo Village has various potential tourist and cultural objects that can attract tourists to visit. As for the various tourism potentials that can be developed in Popo Village, namely the presence of beaches and extensive rice fields, various cultures such as the culture of fishing activities carried out by most of the villagers. Therefore, by developing further tourism potential in Popo Village, it is hoped that it will be able to attract many tourists to visit and get to know the tourist area of Popo Village better. However, on the other hand, various problems will arise in developing the Popo tourist village, including the readiness of the community as an object of tourism, problems with supporting facilities and infrastructure, the form of packaging of potential natural and cultural tourist attractions, the convenience of tourists who come to visit and so on. Thus, this study aims to develop Popo Village as a natural and cultural tourism village area by packaging various existing potentials, so that it becomes a promotional media for Popo Village as a tourist attraction.

Popo village beach should be an important tourism asset in Takalar Regency which contributes high Regional Original Income (PAD) and becomes a means of empowering the community, but in fact this tourist attraction has not been able to contribute to PAD and is efficient in shaping the economic independence of the community. The problem that occurs is that the coastal development of Popo Village as a tourist attraction is not optimal. Likewise, the ideal development of coastal areas involving the three pillars of good governance has not yet been implemented. The lack of facilities and infrastructure, for example, is road access in tourist sites that are still not good, with damaged asphalt roads, lack of infrastructure such as nonexistent lodging, supporting tourist attractions, supporting facilities for recreational facilities, public entertainment and poor beach conditions. preserved.

The coastal development strategy of Popo Village as a tourism object area has not been implemented properly, where the role of the government is very dominant compared to the community, so that the level of community welfare has not been achieved. The absence of an ideal concept has resulted in many problems that arise, even though the coastal area of Popo Village has great potential to be developed. The coastal development of Popo Village has not been able to provide optimal Regional Original Income, improve people's living standards and improve community welfare, but this has not been achieved because the development strategy has not been optimal. The purpose of this research is to find out the right tourism development strategy to be implemented in Popo village as a coastal tourism village in Takalar Regency. 


\section{Methods}

The research design carried out by researchers in order to carry out research activities is to use descriptive research. In this study, researchers tried to find and describe the potentials that exist in Popo village in the form of physical and non-physical potential. Furthermore, by paying attention to these two potentials to find out: development directions, future prospects, and support for Popo Tourism Village. Based on the form and method of implementation, this research is a survey research. This research was conducted in Popo Village, Galesong Selatan District, Takalar Regency, South Sulawesi Province in April-August 2021. The data collection techniques and instruments in this study include; Observation of Data Documentation, Interview and Questionnaire. The respondents of this study were the people of Popo village, and tourists visiting Popo village.

\section{Results and Discussion}

The strategy formulation process includes developing a vision and mission, identifying opportunities, threats, strengths, and weaknesses, setting long-term goals, searching for alternative strategies and selecting strategies for the institution. Likewise with the Department of Culture, Tourism, Youth and Sports which is the drafter and executor of policies in the field of tourism development in Takalar Regency.

The formulation of a tourism development strategy starts from making a master plan in the form of a planning document (Amiruddin, 2020). The planning documents can be in the form of a Master Plan, DED (Detail Engineering Design), as well as a Building and Environmental Planning Plan. As a development of the vision and mission of the Department of Culture, Tourism, Youth and Sports, especially the fifth mission, namely to introduce and expose potential tourism objects and attractions, and other supporting potentials including culture, youth creativity and sports tourism as well as the sixth mission, namely optimizing development tourism objects and attractions, tourism facilities and infrastructure as well as the development of ecotourism based on a people's economy, there are several priorities that must be prioritized, but do not exclude other tourism attractions.

The local government has not yet developed and managed several tourist attractions in the Takalar area because they have to prioritize priority tourism objects. In 2012-2031 development is focused on the Topejawa beach and the Mamminasata area which has been designated by the Central Government as a National Tourism Strategic Area. While the object of alternative tourism and the selection of strategies at the institution. Likewise with the Department of Culture, Tourism, Youth and Sports which is the drafter and executor of policies in the field of tourism development in Takalar Regency. The formulation of a tourism development strategy starts from making a master plan in the form of a planning document. The planning documents can be in the form of a Master Plan, DED (Detail Engineering Design), as well as a Building and Environmental Planning Plan. As a development of the vision and mission of the Department of Culture, Tourism, Youth and Sports, especially the fifth mission, namely to introduce and expose potential tourism objects and attractions, and other supporting potentials including culture, youth creativity and sports tourism as well as the sixth mission, namely optimizing development tourism objects and attractions, tourism facilities and infrastructure as well as the development of ecotourism based on a people's economy, there are several priorities that must be prioritized, but do not exclude other tourism attractions. 
Development Strategy includes; (1) Optimizing the condition of the natural potential that is owned, namely in the form of beautiful beaches and catches of fish that can be packaged attractively to improve the quality and diversity of tourism products; (2) Increasing the diversity of tourist attractions both within the location of tourist objects and raising the potential of natural resources that have not been developed and packaging them more attractively through tour packages, adequate facilities and homestay development as well as developing cultural arts as tourism events to increase tourist attraction and face competition with similar tourist objects; (3) Optimizing the role of management in developing equal potential in each hamlet and continuing development programs such as socialization, training and capital assistance with more frequent and even intensity for the development of homestays and improving the quality of human resources; (4) Improving services through the provision of adequate facilities, infrastructure, and accessibility supported by Takalar Regency policies related to tourism development in order to support the needs and comfort of tourists; (5) Utilizing the availability of local manpower and optimizing community participation supported by local government policies in developing tourist attractions and improving the local economy; (6) There is a need for integrated waste management in Popo Village, especially in each tourist attraction.

Based on the internal and external environmental factors of the tourist village in Popo Village, a SWOT analysis (strengths, weaknesses, opportunities, and threats) was carried out which is an alternative strategy for developing a tourist village in Popo Village, South Galesong District, Takalar Regency. The SWOT matrix produces four possible alternative cells for developing tourist villages according to the potential and conditions of the internal environment and external environmental conditions of Popo Village.

Based on each strategy, various development programs can be described and derived that support the development of the tourist village of Popo Village in particular and Takalar Regency in general.

Table 1. SWOT analysis matrix for tourist village Popo Village, South Galesong Regency

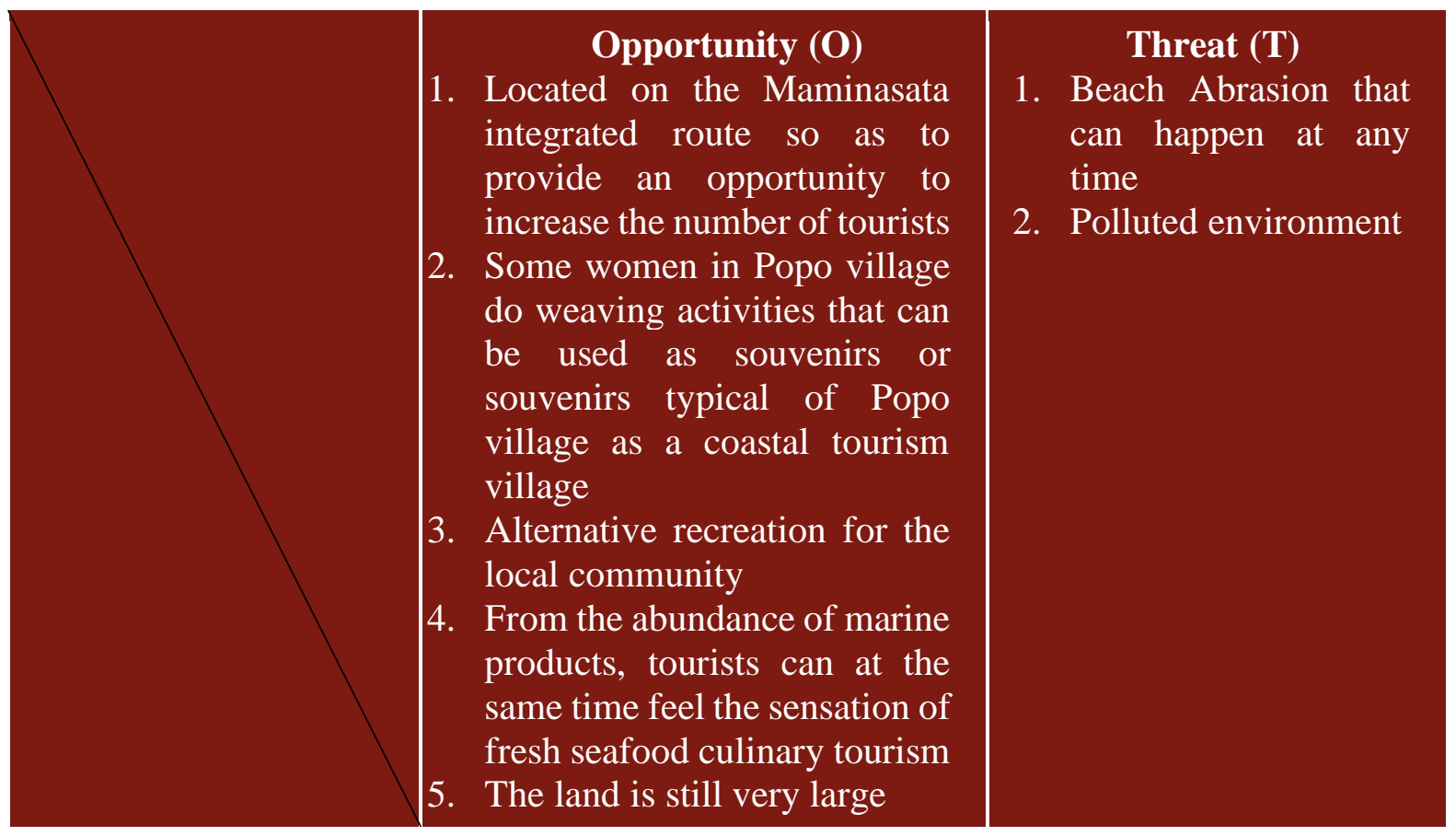









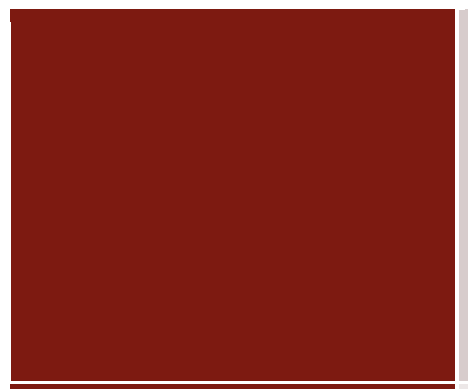

about culture, tourists can also learn the values of mutual cooperation in this activity.

Weakness (W)

1. Lack of Budget
Allocation in
tourism village
management
2. Human resources
who have not been
trained in the
management of
tourist destinations
3. Lack of promotion
of marine tourism
destinations in
Takalar district,
especially in Popo
Village, South
Galesong District
4. Lack of parking
space rad road
5. Inadequate a
infrastructure, lots
of damage and
potholes

1. Lack of Budget Allocation in tourism e

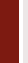
an adequate parking space. because with the new land that is used as a parking lot it will be more comfortable for tourists. The facilities available at a tourism object will trigger an increase in the number of visitors.

2. Cooperating with the creative industry and the community to make handicrafts, food and beverages typical of Popo Village and provide assistance in processing marine products so that they have high economic value. This can open up employment opportunities for local residents and at the same time become an attraction for tourists so that it can increase the number of tourists at Popo Tourism Object.

\section{WT}

1. Utilizing technology as a promotional medium in developing technology-based tourism

2. More showing the development of the coastal tourist area of Popo village in the construction and maintenance of facilities

3. Conducting socialization and assistance for reforestation of coastal areas by planting mangroves to prevent beach abrasion

4. The government of Takalar Regency through the tourism office and the health office provides direction to the community on how important it is to maintain beach cleanliness.

Based on the results obtained by selecting the right strategy by collaborating between internal factors (strengths and weaknesses) with external factors (opportunities and threats), it can be concluded that the Popo Village Tourism Object needs to develop and improve related components (attractions, accessibilities, accommodation, and ancillary). These components will determine whether or not a tourist attraction is comfortable, because basically tourists will feel comfortable and want to come back again if the tourist attraction gives a different and comfortable impression. Community participation is also important to support the development of a tourist attraction. 
Community participation in the tourism village development process will be realized as a real activity if three main factors are met that support it, namely (1) awareness, (2) ability, and (3) opportunities for the community to participate (Frasawi, 2018). In addition, the same thing was also conveyed by Wardani, (2018) that the involvement of the community's role will greatly affect the progress of tourism objects, the community is always involved in various things, namely planning, monitoring, management, entrepreneurs/tourism economic actors who also support good management. in tourism development. It is hoped that with the strategy that has been offered to the Popo Village Object, it can increase the number of visitors and become more widely known. So that with the increase in tourist visits at the Popo Village Tourism Object, it can become a regional income, because considering that the traders who are in the Popo Village Tourism Object location are the villagers themselves. Support from the government is also very much needed so that tourist attractions in Takalar Regency, especially Popo Village Tourism Objects can be managed by being monitored and also promoted so that they can be recognized by domestic and foreign tourists.

\section{Conclusion}

The development of tourist villages requires support from various parties so that they can become income for the community in the tourist village. In the development of tourist villages, there are various factors including driving factors and inhibiting factors. This is also a factor that makes tourist villages exist in Popo Tourism Village. The driving factor of the tourist village being the driving force for the promotion of the tourist village will be a factor inhibiting the development of the tourist village so that it can be accepted and managed so that it can be entered as a tourism partner village.

\section{References}

[1] Amiruddin, H. (2020). Strategy in Promotion E-Tourism Base: Study on Bantaeng Regional Government. Journal La Bisecoman, 1(1), 1-6. https://doi.org/10.37899/journallabisecoman.v1i1.22

[2] Bhuiyan, M. A. H., Siwar, C., \& Ismail, S. M. (2013). Tourism development in Malaysia from the perspective of development plans. Asian Social Science, 9(9), 11.

[3] Brake, W., \& Edward, A. D. D. O. (2014). Tourism and'fracking'in western Newfoundland: Interests and anxieties of coastal communities and companies in the context of sustainable tourism. International Journal of Marine Science, 4.

[4] Fitrianti, H. (2014). Strategi Pengembangan Desa Wisata Talun Melalui Model Pemberdayaan Masyarakat. Economics Development Analysis Journal, 3(1).

[5] Frasawi, E. S. (2018). Partisipasi Masyarakat Dalam Pengembangan Desa Wisata Ambengan Kecamatan Sukasada. Jurnal Pendidikan Geografi Undiksha, 6(3).

[6] Gunn, C. A., \& Var, T. (2020). Tourism planning: Basics, concepts, cases. Routledge.

[7] Kabanova, E. E. E., \& Vetrova, E. A. (2017). Cluster approach as tourism development factor. Journal of Environmental Management \& Tourism, $8(8$ (24)), 1587-1594.

[8] Rusu, S. (2011). Tourism multiplier effect. Journal of Economics and Business Research, 17(1), 70-76.

[9] Saepudin, E., Budiono, A., \& Halimah, M. (2018). Development strategy of education tourism in Cibodas village in West Bandung regency. Journal of Environmental Management \& Tourism, $9(8$ (32)), 1684-1695. 
[10] Siswanto, A. (2015). Eco-Tourism Development Strategy Balurannational Park in the Regency of Situbondo, East Java, Indonesia. International Journal of Evaluation and Research in Education, 4(4), 185-195.

[11] Soekadijo. (2001). Manajemen Kepariwisataan. Jakarta: PT. Gramedia Pustaka

[12] Umar, H. (2010). Desain penelitian manajemen strategik. Jakarta: Rajawali Pers.

[13] Wardani, N. W. N. S., \& Wesnawa, I. G. A. (2018). Potensi Ekowisata Kampoeng Kepiting Di Desa Tuban, Kecamatan Kuta, Kabupaten Badung. Jurnal Pendidikan Geografi Undiksha, 6(1).

[14] Yoeti, O. A. (2008). Perencanaan dan Pengembangan Pariwisata. Jakarta: Pradnya Paramita. 